\title{
Body, Self and Others: Harding, Sartre and Merleau-Ponty on Intersubjectivity
}

\author{
Brentyn J. Ramm
}

check for

updates

Citation: Ramm, B.J. Body, Self and Others: Harding, Sartre and Merleau-Ponty on Intersubjectivity. Philosophies 2021, 6, 100. https:// doi.org/10.3390/philosophies6040100

Academic Editor: Kristie Miller

Received: 5 October 2021

Accepted: 29 November 2021

Published: 3 December 2021

Publisher's Note: MDPI stays neutral with regard to jurisdictional claims in published maps and institutional affiliations.

Copyright: (C) 2021 by the author. Licensee MDPI, Basel, Switzerland. This article is an open access article distributed under the terms and conditions of the Creative Commons Attribution (CC BY) license (https:// creativecommons.org/licenses/by/ $4.0 /)$.
Department of Psychology and Psychotherapy, Witten/Herdecke University, 58448 Witten, Germany; Brentyn.Ramm@uni-wh.de

\begin{abstract}
Douglas Harding developed a unique first-person experimental approach for investigating consciousness that is still relatively unknown in academia. In this paper, I present a critical dialogue between Harding, Sartre and Merleau-Ponty on the phenomenology of the body and intersubjectivity. Like Sartre and Merleau-Ponty, Harding observes that from the first-person perspective, I cannot see my own head. He points out that visually speaking nothing gets in the way of others. I am radically open to others and the world. Neither does my somatic experience establish a boundary between me and the world. Rather to experience these sensations as part of a bounded, shaped thing (a body), already involves bringing in the perspectives of others. The reader is guided through a series of Harding's first-person experiments to test these phenomenological claims for themselves. For Sartre, the other's subjectivity is known through The Look, which makes me into a mere object for them. Merleau-Ponty criticised Sartre for making intersubjective relations primarily ones of conflict. Rather he held that the intentionality of my body is primordially interconnected with that of others' bodies. We are already situated in a shared social world. For Harding, like Sartre, my consciousness is a form of nothingness; however, in contrast to Sartre, it does not negate the world, but is absolutely united with it. Confrontation is a delusion that comes from imagining that I am behind a face. Rather in lived personal relationships, I become the other. I conclude by arguing that for Harding all self-awareness is a form of other-awareness, and vice versa.
\end{abstract}

Keywords: phenomenology; the body; the self; others; intersubjectivity; Douglas Harding; Jean-Paul Sartre; Maurice Merleau-Ponty

\section{Introduction}

The problem of other minds became particularly pronounced with the mind-body dualism of Descartes. Beginning from first-person experience, Descartes argued that since my sensory experience was open to doubt, the only certainty was the existence of my own existence as the experiencer (the cogito) [1]. Furthermore, in the Cartesian tradition, I receive the other's physical body through the senses, but not their mind (which is metaphysically and conceptually distinct from their body), and thus the question becomes how does the disembodied cogito know the cogito of the other? If the cogito can only have indubitable knowledge of itself, then it is already in some sense closed off from the world. If other cogitos exist, they would likewise be sealed off in their own self-knowledge, and there would be no certain knowledge of the other. In fact, the knowledge of others is doubly problematic on the Cartesian account because I must be skeptical of the existence of both others' minds and others' bodies. Furthermore, even if their body does exist, they may be some kind of automaton without a mind.

In reaction to Descartes, phenomenologists reject mind-body dualism and metaphysical abstractions, as a thing-in-itself behind the 'appearances' of objects. By rejecting dualism, the skeptical question of whether I know that others have minds tends not to arise. However, even taking for granted that I know others' minds, the question of how I know them is still a pressing one. In particular, even if there is no epistemological problem, 
if the concept I have of mental states is derived from my own first-person case, there is a threat of conceptual solipsism. Wittgenstein [2] (section 302) posed the problem as follows:

If one has to imagine someone else's pain on the model of one's own, this is none too easy a thing to do: for I have to imagine pain which I do not feel on the model of pain which I do feel. That is, what I have to do is not simply to make a transition in imagination from one place of pain to another. As, from the pain in the hand to pain in the arm. For I am not to imagine that I feel pain in some region of his body.

It seems then, when starting from one's own experience, that the only mental states I can think of and truly understand are my own. I will be concerned with this second category of the problem of other minds here, rather than the epistemological category.

Phenomenology has been given many definitions over the years but is typically considered to be an analysis of the intentional structure of consciousness [3] (p. 64) or more generally 'the study of structures of consciousness as experienced from the first-person point of view' [4] (p. 1). Like the Cartesian approach, the subject matter of phenomenology is what is given from the first-person perspective. According to Husserl, the phenomenological approach involves looking disinterestedly 'to see and to describe adequately what they see, purely as seen' [5] (p. 35). However, a significant problem that arises for the phenomenological method is that the subjectivity of others always transcends my own. If the initial goal of the phenomenological approach is to study one's own 'consciousness of' the world, then the problem of others may be built into (and implicit in) the very methodology.

I do not experience another's perspective, nor their experiences of sight, touch, smell, etc. How then do I relate to others' mental contents, intentions, desires, and emotions? How does my consciousness relate to the consciousness of others? A central challenge for phenomenology hence becomes the explication of intersubjective relations, and this opens up the question of whether phenomenology slides into conceptual solipsism. Is phenomenology inevitably trapped within its own subjectivity? Phenomenologists have hence been deeply concerned with the embodiment of the subject and intersubjectivity. Husserl described the communal 'life-world' in which we are embedded, making intersubjectivity built into our experience of the world [6]. While Sartre preserved some aspects of Cartesian dualism, in his assumption of a nihilating consciousness that can negate the world, we find in Heidegger and Merleau-Ponty non-dualistic philosophies with an emphasis on our body's primordial, pre-reflective connection with others and the world ${ }^{1}$. Thus, the body and intersubjectivity came to be of foreground importance for phenomenology.

Douglas Harding (1909-2007), was a twentieth century philosopher and mystic who also wrote extensively on the phenomenology of the first-person subject, the body and intersubjectivity. He wrote his philosophy outside of the academy, and thus his work is not well known in this context ${ }^{2}$. Though he rarely engaged directly with the phenomenological tradition, his first-person exercises ('the experiments') are clearly a phenomenological approach in a broad sense of 'phenomenological', i.e., a method which has a rigorous investigation of first-person experience as an essential component ${ }^{3}$.

Harding's phenomenology was primarily inspired by nondual religious traditions such as Buddhism [16-18] and in particular the mysticism of the Perennial Philosophy [19]. However, rather than taking them on faith he always sought to test the truth or falsity of religious claims (and common-sense claims) by reasoning, consistency with science and direct experience. He saw what he was doing as de-mythologising religious insights and bringing them within the ken of rigorous empirical methods (a first-person science) [20]. He argued that that which survived these tests was a version of the mysticism at the heart of all of the major religions [21] (pp. 102-105).

Philosophical phenomenology can be historically traced from Brentano through Husserl to Edith Stein, Martin Heidegger, Jean-Paul Sartre, Maurice Merleau-Ponty, and many others. Though in addition to Franz Brentano, William James and Ernst Mach can also be thought of as important precursors to the phenomenological movement [22,23]. Additionally, phenomenology split from Brentano in an empirical branch instigated by 
Carl Stumpf. In particular, Stumpf's students Wertheimer, Koffka and Köhler developed the Gestalt tradition. Douglas Harding's radical empiricism can be understood to have components of both a descriptive phenomenology and experimental phenomenology (on the latter see [24-28]). Unlike many phenomenologists, however, he uses phenomenology to motivate metaphysical theories, so in this sense he is more of an empiricist than a phenomenologist.

Harding's first-person experiments were developed for testing who or what I am in my own experience. His awareness exercises count as experiments in the sense that they use apparatus such as pointing fingers and mirrors for guiding attention and for assisting in making phenomenal contrasts [21]. One of the goals of the paper will be to compare and contrast Harding's philosophy with the phenomenological tradition, particularly with the philosophy of Sartre and Merleau-Ponty.

Harding began by contrasting the first-person experience of one's body with the third-person perspective of others' bodies. He pointed out that when looking at others' bodies, I see a complete body with legs, arms, torso and head. However, when I perceive my own body, I can see my legs, torso and arms, but not my head. Harding noticed this after coming across a first-person self-portrait drawn by Ernst Mach. The image, depicted in Figure 1, is of Mach's first-person self-portrait with one eye closed. In the background it shows a wall and a window, wooden floorboards and shelves of books along the wall. In the middle ground it shows Ernst Mach's body, in particular, his shoes, wrinkled pants, waistcoat, and arms, and right hand holding a pencil. In the foreground, on the right can be seen a large nose blur and handlebar moustache, and at the top, an eyebrow. At the edges the image fades out.

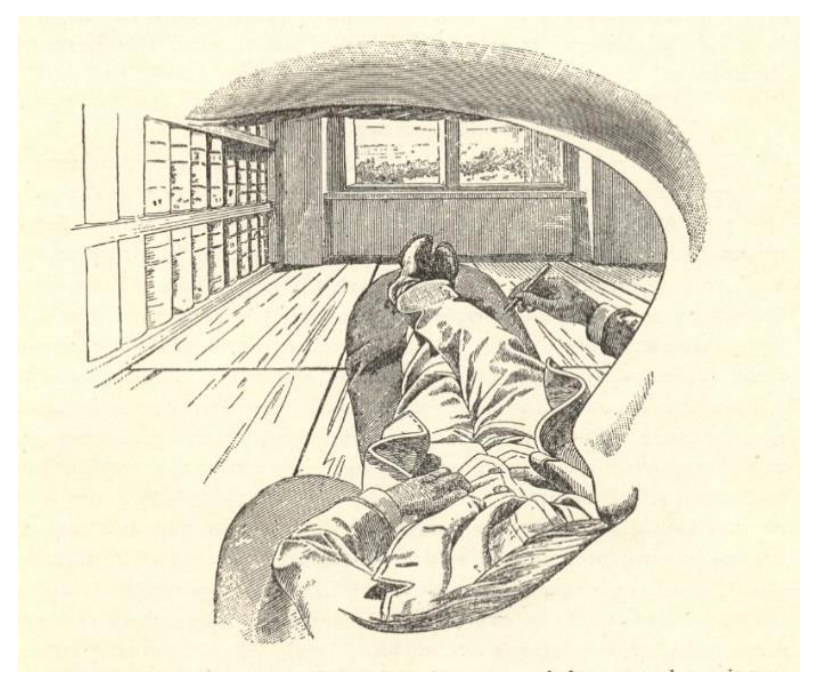

Figure 1. Ernst Mach's first-person self-portrait [29] (p. 59). Reproduced with permission of the Oxford University Press.

Both Sartre and Merleau-Ponty were aware of the difference between first-person and third-person perspectives upon one's own body, in particular the visual lack of a head here. Sartre gives the example of reading:

The object of my consciousness is the book and across the book the truths which it points out. The body is in no way apprehended for itself; it is a point of view and a point of departure. The words slip by one after the other before me; I make them slip by ... In all this the body is given only implicitly; the movement of my eyes belongs only to an observer's glance. For myself I apprehend thetically only this fixed upsurge of words one after the other... It is impossible for me to distinguish the movement of my eyes from the synthetic progression of my 
states of consciousness without resorting to the point of view of the other. [30] (pp. 436-437)

Merleau-Ponty also noticed that we cannot see our own heads, stating 'In the matter of living appearance, my visual body includes a large gap at the level of the head' [31] (p. 108). Harding's advance was in noticing the implications this has for the nature of the self and in developing experiments for investigating this gap.

Two of these experiments are given below (Experiment 1 and Experiment 2). The goal of these exercises is to direct your attention to what you are looking out of in your own first-person experience. As these are phenomenological exercises, it is vital that you temporarily drop pre-conceptions, memory and imagination and simply notice what is given in experience ${ }^{4}$. Please do the following:

\section{Experiment 1: Pointing}

Look at your finger and notice that it has colour, shape, and textures. With this thing, by pointing, direct your attention to a far wall. Notice its colour, opaqueness and extension. Now point to the floor. Notice the patterns, colours and textures. Now point to your foot. Once again you are pointing at a shaped and coloured thing. Now very slowly, tracing your pointing finger up your body, notice that the object-to-object duality persists. Now bring your finger up in line with where you are told is your face. From your present experience is your finger pointing at an object or is there no longer any duality? Is there a head or face here? Are there any colours or shapes here? Or are you pointing at no-thing? My experience is of an arm and pointing finger and the room beyond, but on this side of the room there is only an empty space (the entire back wall is missing). However, this transparent opening, or gap, also contains the room. This gap is also not in anything. It has no boundaries. In fact, this is no absolute nothingness, rather it is awake to itself and the world. Is this true for you ${ }^{5}$ ?

\section{Experiment 2: Holding Your Ears}

Gently take hold of your ears with your hands. Focus on the blurs in the periphery of your vision. Now please answer the following questions. On present evidence is there a head between these blurs? Are there any eyes? Are there any colours or shapes? Is there a head? Now attend to your 'ear' sensations. How far apart are they? Is this a head sized gap or is it world-wide? Is the gap bounded by anything or is it boundless? Is there on present evidence a head between your ears or the world itself? Are the 'head' sensations between your 'ears' currently forming an opaque hairy-flesh-ball or are they transparent and in the same space as the scene ${ }^{6}$ ?

As with Merleau-Ponty, all I find is a gap or a void here. However, this void is special in that I am looking from here-it is self-evidently aware ${ }^{7}$. It also encompasses the scene. This void is so totally united with the world, that it would be just as valid to say that the world is between my 'ear' sensations. That is, the world itself is on my shoulders [14] (p. 107). On the first-person's radical openness to the world Harding remarks 'I am at large in the world. I can discover no watcher here, and over there something watched, no peep-hole out into the world, no window-pane, no frontier. I do not detect a universe: it lies wide open to me' [14] (pp. 107-108).

Of course, I see my face in the mirror, but as an infant I did not recognize the face as my own, but rather it seemed to belong to another infant. In fact, infants cannot recognize their face in the mirror as their own until 18 months of age [35]. Mirror self-recognition has been taken as an important indicator of self-awareness, and experiments show that it is also found in some non-human animals such as great apes [36,37] and dolphins [38], amongst others. Species that do show this ability also tend to be the ones that have more complex social structures. This indicates that as social relations become more advanced, 
there is a greater need for an entity to take into account the view of others, that is, what it looks like to others.

Harding analysed the development of one's third personhood in terms of the young child learning to play the 'face game'. In particular,

(the child) learns to pretend that $\mathrm{s} /$ he is what $\mathrm{s} /$ he looks like. She persuades herself that her central reality — what she is in her own experience at zero metresresembles her regional appearance over there at, say, two metres, picked up by us, her observers. She comes to believe that she finds, right where she is, a human something, a face, a substantial body ... Now for her it is exactly as though she were coming from a human something which is shutting us and everything else out, instead of from a non-human no-thing or absence which cannot help taking it all in [39] (p. 99).

One potential criticism of Harding's approach is that it shows an over reliance on vision. According to Levinas, the West's emphasis of vision over the other senses places a distance between subject and object, self and other, while Irigaray points out that vision has traditionally been used by men to objectify women and to make them into passive objects of their gaze ${ }^{8}$. By contrast, however, Harding reveals vision as a form of radical openness, such that when I am consciously 'headless' the separation between myself and others drops away entirely. Their face is not "an other" but my very own. I am the other. The same is true for the other senses. I hear the other's voice, not my ear drums. Nothing gets in the way of the other's voice. It is a way that I am manifesting in that moment ${ }^{9}$. Later in this paper, I will also discuss examples of the first-person experience of other senses such as touch and hearing in the relation between self and others.

One major presupposition leading to the problem of other minds is taking a thirdperson perspective upon others and myself. Whether explicitly, or implicitly, we treat minds as ghostly substances that are separated from each other by somehow residing in our separate heads. Harding challenges this assumption, by pointing out that there is no head here to get in the way of the world from the first-person perspective. I am in no way closed off from others but built open to them. I would like to argue that noticing this phenomenological reality represents an advance in considering our self-other and self-world relations.

However, in the 'headless' experience, the 'I' seems to have been lost altogether in the other. It seems therefore to be a case of being-the-other rather than relating to the other, and thus cannot be properly called an intersubjective relation [44]. The question thus arises of how the view can account for the human experience of engaging in interpersonal relationships? I will address this question in the paper by discussing Harding's conception of where the self fits into this picture. Though I cannot see my face from the first-person perspective, I operate within the social realm as if I have a face. My facial expressions are used for social communication, precisely because I already assume they are experienced by the other. In fact, all self-awareness is a form of other-awareness.

I will consider Douglas Harding's radical empiricism in the light of Sartre and MerleauPonty's philosophical perspectives and vice versa. I will discuss Sartre's notion of 'The Look' as well as Merleau-Ponty's body-subject and criticisms of Sartre. My main thesis is that the first-person experience of our own bodies as presented by Harding illuminates the question of how I relate to others from the first-person perspective. In particular, it shows that the experience of my body presupposes the perspectives of others, and my encounter with others is primordially one of openness.

\section{Sartre on 'The Look' and Objectification of the Subject}

Both Sartre and Merleau-Ponty were strongly influenced by Heidegger. Reacting against Husserl's transcendental approach and its emphasis on transcendent subjectivity (with its Kantian language), Heidegger [45] famously sought a non-dualistic explication of the body and intersubjectivity in terms of our being-in-world [46] (p. 84). This 'being in' does not refer to a spatial containment in the world, but rather an involvement or 
everyday engagement with the world. Zahavi [3] argues against the caricature of the Husserlian disembodied consciousness and shows how Husserl anticipates Sartre and Merleau-Ponty's analyses of embodied phenomenology. Nevertheless, both Sartre and Merleau-Ponty take Heidegger's investigation of our being-in-the-world and an emphasis on the embodiment of self, as a major advance, particularly as evidenced by their adoption of Heidegger's terminology ${ }^{10}$.

In Being and Nothingness, Sartre distinguishes between two ontological categories: the in-itself and the for-itself. The in-itself refers to the being of the phenomenal world. The in-itself is non-conscious and simply what is. The for-itself is consciousness. Consciousness is nothingness or non-being. Sartre understands the non-being of consciousness as a type of negation of being. Non-being cannot exist separately to or prior to being (he is not positing a form of Cartesian dualism), because it is merely a negation or contradiction of being [30] (p. 49). Sartre gives the example of looking for Pierre in a café. I expect him to be there, but he is not there. The café, its objects and occupants are being. As I look for Pierre, however, these things become a mere ground against which I seek Pierre. The café is nihilated in favour of Pierre. However, Pierre is not there. I directly apprehend his absence from the cafe, his non-being. It is from non-being that I judge he is not there. According to Sartre, this ability of the for-itself to nihilate being is the source of its absolute freedom [30] (pp. 40-41).

For Sartre, I encounter others directly in my being-for-others [30] (pp. 340-400). In particular, I directly encounter others when they look at me. Before that, the other can be objectified-the other is seen as both an object and a person. A man in a park is seen simultaneously as being a certain distance from the lawn, but also as having a perspective upon the lawn which escapes me. Sartre describes this experience as the world having a kind of drain hole or crack in being. Yet still the other is an other-as-object. It is only when he or she looks at me that I directly encounter the other's subjectivity. Sartre gives the example of shame. I am listening at a door and looking through a keyhole. I am immersed in the scene, there is no self, there is just the scene. However, then I hear a creak, I have been seen by another. I am engulfed by shame, and in that feeling of shame I become an object for the other. Under the other's gaze I become an object in the world. Thus, The Look and seeing the other as an object are incompatible. I am simply conscious of being looked at. The Look pierces me to the heart of my very being. In experiencing another's subjectivity, I become an object for that subject. As pure consciousness, I am absolutely free, but when I am looked at, I become an object for the other's freedom. It is a possibility for me to hide in the dark corner, but I also apprehend that the other can surpass this possibility by shining the torch on it, and thus 'in the look the death of my possibilities causes me to experience the Other's freedom' [30] (p. 362).

Our relations with others then are inherently ones of conflict-an unstable dynamic in which I assert my freedom by looking at the other as an object and in which they can turn the tables by doing the same to me. Drawing upon Hegel, I can only ever be subject or object, master or slave. For Sartre, then, I experience the other's body predominately as an object. The other's body is to be distinguished from other objects only in that it is the vehicle for the manifestation of The Look, 'my apprehension of the Other in the world as probably being a man refers to my permanent possibility of being-seen-by-him' as an object [30] (p. 345).

I am not only objectified when others look at me, I can also objectify myself. Sartre illustrates the disabling effect of the consciousness of oneself as an object in the case of a waiter he observed in a café:

His movement is quick and forward, a little too precise, a little too rapid. He comes toward the customers with a step a little too quick. He bends forward a little too eagerly; his voice, his eyes, express an interest a little too solicitous for the order of the customer. Finally there he returns, trying to imitate in his walk the inflexible stiffness of some kind of automaton while carrying his tray with the recklessness of a tightrope-walker ... All his behaviour seems to us a game. He applies himself to chaining his movements as if they were mechanisms; he 
gives himself the quickness and pitiless rapidity of things ... He is playing at being a waiter in a café. [30] (pp. 101-102)

Harding comments:

Let us take up the story. If, instead of playing at being a waiter in a café, he were to see that in his own immediate experience he is the café itself, along with all that is going on there (including those limbs of his, going about their own business), why, this phony and ineffectual waiter would turn into the opposite sort. If, instead of pretending to be a thing, he were to come off it and be no-thing: if he were to be himself for himself, he would be for others one of the best waiters in Paris instead of one of the worst. True to his reality, he would appear false to none. [48] (pp. 11-12)

A number of themes emerge from Sartre and Harding's analysis of this case. Sartre and Harding seem to agree that self-awareness of oneself as a mere thing is a kind of game- - false consciousness. For Sartre, in particular, it is one of the ways in which I act as if I have a fixed nature and hence deny my absolute freedom. For Harding, it is the root of the human condition. This delusion of being merely a thing and hence separate from others and the world is one of the primary sources of human suffering-it is the basis of greed, hatred and ignorance.

The case also raises the question of how exactly one can be a waiter authentically without merely play acting. Sartre does not tell us how to do this. Harding, on the other hand, proposes a remedy for this dreadful form of self-consciousness-that of directly noticing one's non-thing-like nature and acting from this awareness. In particular, noticing that the lived experience of waitering is being space for the café, or more precisely being the café.

Harding creates a new verb for describing how the waiter is going wrong. He things himself [48] (p. 11). This brings out the voluntary nature of self-consciousness. For Sartre, self-consciousness is often something involuntary. It is something that happens to us when others look at us. By contrast, Harding holds that this is a habit, albeit a rather strong one, that we have learnt. It is something that we do to ourselves. As it is a habit it can be unlearnt. Afterall, if The Look of the other always made us into an object, then performing in front of an audience would be next to impossible. In being consciously aware that I am not a thing at all, but space for the audience and everything happening on the stage, including the voice issuing from the void, then stage fright naturally dissipates. The antidote to being shame-faced is to be consciously aware of your facelessness [48] (p. 59).

The voluntary nature of self-consciousness suggests that even the power of The Look can be turned on its head. The other's look is a kind of arrow of attention that we cannot help but follow, much like a pointing finger. As such, this suggests another awareness exercise that we can test out. Suppose that when someone looks at me, rather than imagining how I appear to them from over there, I see what they are looking at in my lived experience. Then their gaze will be seen to be looking into unbounded emptiness. The practical effectiveness of these techniques is, of course, something to test out for oneself.

\section{Merleau-Ponty's Body-Subject}

One of Merleau-Ponty's primary innovations in philosophy was his notion of the bodysubject [31]. According to Merleau-Ponty, my body is my subjectivity and my subjectivity is my body. Merleau-Ponty rejects Cartesian mind-body dualism, and Sartre's own stark duality between being-for-itself and being-in-itself. Rather, the body-subject is neither physical nor spiritual but both: it is an ambiguous unity of body and spirit. According to Merleau-Ponty, the body itself has its own intentionality and understanding. The body pre-reflectively "knows" how to drive a car or walk downstairs. In this Merleau-Ponty follows the lead of Heidegger. Additionally, the body-subject is situated in the world. We experience the world as space for our bodies to move in - an object is left or right, high or low, close or far. Thus, the body is in dialogue with the world at a pre-aware level, in which 
the body shapes the world, and the world shapes it [49]. Thus, there is a vague rather than clear boundary between the body-subject and the world.

In terms of intersubjectivity, it can be seen from this that I do not just see a body or object when I see another, but a subject, a person, and since their mind and consciousness cannot be considered apart from their body, there is no problem of accessing an "interior" subjectivity. In particular, the intentions of others are not known by analogy, such as by recalling my past feelings associated with a bodily action, rather they are seen directly. For example, in seeing someone stamp their feet and their face go red, I do not infer that they are angry, I directly read the anger itself in their face and body.

It is important to point out that for Merleau-Ponty these gestures are not understood intellectually, rather:

The communication or comprehension of gestures comes about through the reciprocity of my intentions and the gestures of others, of my gestures and intentions discernible in the conduct of other people. It is as if the other person's intention inhabited my body and mine his. [31] (p. 215)

As an example, if I beckon someone to come over to me, I read their consent or refusal directly in their body. My frustrated bodily response at their refusal occurs without an intervening representation but emerges directly from the social situation. This communication occurs at the bodily level without any explicit thought. Both of our bodies form a single system [31] (p. 127). In this sense, my body is primordially interconnected with others. The social world is a dimension of my very being [31] (p. 421).

Even prior to enculturation, my body already shares intentional possibilities with that of others. As an example, if I pretend to bite a baby's finger it will open its mouth in response, even though it has had limited exposure to a mirror. This shows that biting is tacitly understood within its body as intersubjectively significant. My intentions are perceived in its body [31] (p. 410) ${ }^{11}$.

However, Merleau-Ponty goes on to qualify that understanding others' gestures often depends upon the acquirement of shared cultural meanings. A child does not understand sexual intercourse, before reaching sexual maturity. That is, understanding relies upon our own possibilities of bodily action. I must already have entered the realm of sexual meanings. Similarly, I must be initiated into a culture, learning gestures in their concrete social contexts, before I am able to read these gestures' full meanings.

I also inhabit a communal world filled with shared 'cultural objects' such as artifacts such as chairs, tables and tools. Since artifacts can be used by anyone, not just specific individuals, Merleau-Ponty says 'In the cultural object I feel the close presence of others beneath a veil of anonymity. Someone uses the pipe for smoking, the spoon for eating, the bell for summoning' [31] (p. 405).

Merleau-Ponty criticizes Sartre for making intersubjective relations predominately ones of conflict, arguing that the possibility of conflict presupposes a shared social world. Thus, for example since a dog does not share the human community, its gaze causes me no embarrassment. Merleau-Ponty does not deny the power of another's gaze but sees its positive or negative effects as situated in a pre-existing social context. The other's gaze does not turn me into an object, rather I feel like an object under the other's gaze if I am being observed like an insect or if I feel that the other is denying my perspective. To recognise the other as looking at me is already to presuppose knowledge of an intersubjective world. Additionally, even the refusal to communicate is a form of communication [31] (p. 420). Thus, The Look is not required for communication ${ }^{12}$.

\section{First-Person Experience of the Body}

Having introduced the views of Sartre and Merleau-Ponty on intersubjectivity, I will now discuss Harding's view that experiencing my body presupposes the perspectives of others.

Harding observes that there is a profound difference between the first-person and the third-person perspectives upon my body. For others I am an object in the world, an object that is special in that it is a living human being, but an object, nonetheless. From 
the first-person perspective, however, I only see parts of my body. I cannot see my head, face, eyes, ears. My head is reflected in mirrors, and shiny surfaces, but it is shrunken and pointing the wrong way. It is also in others. From the other's perspective I am a complete human after all and an object in the world. However, from my perspective, to say that I am in my head, or even in my body is a distortion of the experiential facts:

Somehow or other I had vaguely thought of myself as inhabiting this house which is my body, and looking out through its two little round windows at the world. Now I find that it isn't like that at all. As I gaze into the distance, what is there at this moment to tell me how many eyes I have here-two, or three, or hundreds, or none? In fact, only one window appears on this side of my façade, and that one is wide open and frameless and immense, with nobody looking out of it. It is always the other fellow who has eyes and a face to frame them; never this one. [12] (p. 5)

Even if I cannot do so visually, Harding asks whether perhaps if I go by the sense of touch, it will demonstrate that I am looking out of a head after all? He observes that as I touch my 'head' without doubt there are varying touch-feelings which I associate with hair, forehead, nose, and cheeks. However, to make this connection is to refer to a memory, a label, or third-person image of hair, foreheads, noses and cheeks. Furthermore, these feelings dissipate as quickly as they arise. The same applies to the tickles, itches, tensions, eye-sensations, etc. They come and go, but never add up to a solid, opaque ball. Rather, these feelings occur within this transparent awareness:

As for these lurking aches tickles and so on, they can no more quench or shade this central brightness than these mountains and clouds and sky can do. Quite the contrary: they all exist in its shining, and through them it is seen to shine. [12] (p. 9)

One potential challenge to Harding's approach is phenomenologist's denial of pure sensations. Rather all perception is infused with meaning. I do not just see a colouredand shaped-thing moving over there, but a person walking with intention towards the house. Similarly, might it not be said then that these forehead-sensations inherently refer to a forehead in a specific location and as part of a head? Harding does not deny that perceptions are meaningful, but his point is that at least some aspects of this meaning must be developmentally acquired (e.g., what my face looks like and feels like when touched). I learn to associate these 'sensations' with that image and thus imagine or infer that I am looking out of a precisely shaped head-object.

Perhaps my ordinary personal head is indeed experienced as a whole that is in some sense permanent. Even in this case, it is a very different whole from that of others' heads, particularly because it is transparent and manifests inseparably from the given world ${ }^{13}$. Harding's view is that ultimately the perception that there is a head here like what others have is developmentally built up and, in any case, always occurs in this aware-emptiness. That is, these considerations do not eradicate the reality of this void here. Furthermore, to be aware of this as a 'head' is to already have shifted my centre to the other's perspective where I manifest as a person. That is, self-awareness of my body always involves bringing in another's perspective.

What about with eyes closed or for a blind person? Harding asks that we try Experiment 3:

Experiment 3: Eyes Closed

With eyes closed please carefully attend to your bodily sensations. On present evidence how many toes do you have? How big are you? Can you find any clear boundaries, or limits that make up a body in which you are enclosed? Is there a clear point where your body ends and the chair begins? Try touching your body with your hand. Can you build up a solid, precisely-shaped body that exists all at once? Are these touch sensations on the surface of a body, or are they in a single awareness that includes thoughts, feelings, sounds and swirling blackness ${ }^{14}$ ? 
I find much the same story as with eyes open when I am not looking at my body. Sensations come and go in empty-space but they do not add up to a solid, unchanging body. Furthermore, the boundaries between my body and the world are vague. As I sit in my chair, I can feel no clear point where my body ends and the chair begins.

Even with eyes open, my legs, arms and torso are not always visually available, but are constantly reappearing from and then disappearing back into the 'void'. However, what of my conviction that I do have legs, arms, torso and head? According to Harding, I believe this because I habitually and unthinkingly take on the perspective of others upon myself. I jump out of my body a few metres away to where others see me as a human and graft this third-person perspective onto these shapeless sensations. In other words, to experience myself as having a complete, permanently persisting human body presupposes the perspective of others (or at least potential others). The problem of other minds, hence, finds its complement in the problem of my own body. Setting aside metaphysical abstractions and describing how things are concretely given, one could say that I know my body in others and others in my body.

Merleau-Ponty and Sartre also noticed the visual absence of a head here. MerleauPonty used this first-person experience to criticize classical psychology for defining the body as an object. Though I only ever see one side of an object at a time, I can at least go around it. However, my body is not arranged before me as an object. It is a permanence that is always there, but not one that can be inspected like everyday objects. In a passage that resonates with the reflections of Harding, Merleau-Ponty states:

My head is presented to my sight only to the extent of my nose end and the boundaries of my eye-sockets ... My visual body is certainly an object as far as its parts far removed from my head are concerned, but as we come nearer to the eyes, it becomes divorced from objects, and reserves among them a quasi-space to which they have no access, and when I try to fill this void by recourse to the image in the mirror, it refers me back to an original of the body which is not out there among things, but in my own province, on this side of all things seen. [31] (p. 105)

The first-person view of the body is thus profoundly different from that of classical psychology's third-person view in which the body is a system of muscles, bones and sinews, operating in objective space. This is because it is through my body that there are objects. It is my view-point upon the world, and thus cannot be an object in the third-person sense. He holds that if classical psychology had more carefully reflected on the body's particular mode of permanence, rather than being another object in the world, the body would have been seen as 'our means of communication with it' [31] (p. 106). However, for the purposes of science, the lived body is reduced to a mechanical object in the world, while the body as experienced for the first-person is reduced to a mere representation of a body in consciousness.

Like Merleau-Ponty, Sartre also observed that I cannot see my own body as perceiver. In particular, he points out that in perceiving, I do not perceive the organ of perception (such as my eyes in seeing, ears in hearing, etc.) [30] (p. 402). This being said, my body is a continual presence, it is implicit during every perception because it is my viewpoint upon the world. However, the body is not an instrument of perception, rather it is revealed to us by our relations with the world ${ }^{15}$. Again, there are many similarities with MerleauPonty. For example, Merleau-Ponty, holds that objects are known through our ability to manipulate them, move around them, etc., but that the body is also known through its manipulation of objects, and thus the persistence of phantom limbs in the case of amputees is partly because objects 'in so far as they present themselves as utilizable, appeal to a hand I no longer have' [31] (p. 95).

This unity of the body and the world is also consistent with Harding's first-person experiment with touch, in which he observes that there is a vague boundary between my bodily experience and the things with which it 'interacts'. In a sense, it could be said that my hand gains its solidity only in action, in particular in its grasping of objects, etc. 
Furthermore, this seems to dovetail with Merleau-Ponty's claim that the body-subject is open to the world [31] (p. 530).

To verify this please try the following Experiment 4 . I will report my experience and you can see if the same is true for you:

\section{Experiment 4: Touch}

Close your eyes and touch a chair or other object and notice the experience. Do you feel the chair or your hand or both? As I touch the chair, I feel its texture and shape but not that of my hand and its fingers. It is as if my hand transforms into whatever it touches. However, as I explore, I distinguish different areas of pressure. I can feel the position of what I imagine as an arm and hand. In the action of exploring I can briefly individuate centres-of-touching-activity, which I associate with a thumb, fingers and palm. There are different areas of pressure and texture, but I cannot distinguish five such areas (fingers) simultaneously. I can intend that a different area of texture/pressure become more pronounced, which I imagine as 'pressing with a finger'. The presence of my hand and fingers are activated during the exploring, but as regions of touching activity, rather than as solid static things with a separate existence. My fingers and skin in general are centres of touching and feeling that are exhausted by things touched and felt ${ }^{16}$.

That my phenomenal body cannot be a thing, but rather must be space-for-the world is also a purely logical point. If I felt my fingertip at the same location as the thing being touched, the sensations would interfere with each other. The feeler has to be empty to take on the thing felt. Similarly, I see the sky not my eyes, I hear the sounds of birds not my ears, I smell the laksa cooking not my nose and taste the chocolate not my tongue ${ }^{17}$. As Giles points out, in general my first-person body is my perception of the world:

The hand which allows me to feel the fluidity of the water, the warmth of the air, or the texture of my other hand, is not the hand which enters into my perception of the world; it is my perception of the world. More precisely it is my manual tactile perception of the world. Thus, from the first-person perspective my body is a maze of centres of perception which constitute my phenomenological point of view on the world. [58] (p. 108)

One challenge to the view presented so far is the case of proprioception and somatic experience. Surely these are clear bodily experiences that do not involve the world? Consider proprioception (one's awareness of body and limb position). I can walk downstairs in the dark, catch a ball without seeing my hand, and can tell if my legs are crossed. MerleauPonty gives the example of one's ability to locate and scratch a mosquito bite without seeing it [31] (pp. 118, 121, 140-141). Much of my awareness of my body in space and how its parts are spatially related is seemingly tacit. It is always in the background.

Giles [58] argues that the body parts from the first-person perspective are themselves points of view onto the world, so proprioception is really just the sense of the changing spatial relations between these points of view. Furthermore, subjects in flotation tank studies, in which the perception of "external" objects is entirely absent, will often report a total loss of bodily experience, including proprioception $[59,60]$. This again suggests that much of my sense of embodiment supervenes on my experience of interacting with the world.

Somatic experiences, such as the hunger pangs of my stomach and tension in my forehead, do not require a particular sensory organ, so perhaps they could be considered direct experiences of my body? However, as Giles argues these sensations are also presented as objects of awareness. I take a point of view upon them not unlike the point of view I take upon my abdomen in visual experience [58] (p. 109). It seems then that the body as feeler can be considered a collection of points of view onto the world (including some of my body's inner states), plus the relations between these points of view.

Proprioception and somatic experiences do not undermine the position argued for so far that my objecthood comes from taking a third-person view upon myself. In particular 
one can ask in regard to these types of bodily experience: is the body presented as a precisely shaped object? Am I in these proprioceptive limbs and somatic perceptions or are they in my awareness? Confining these feelings within the boundaries of a physical body, rather than sensing them as vague phenomena in space, seems to require that I imagine them from the third-person perspective. Alternatively, it requires that I take a third-person perspective upon myself. For example, if I look at my abdomen while tensing my stomach then the tension does indeed seem to be in my body. Though then the body itself is in my visual field and so still in consciousness. Finally, none of these experiences seems to undermine my body's radical openness to the world, including to parts of the body itself.

Without precise spatial boundaries, the phenomenal body seems to be more like a pure potential for action, rather than an object moving through space. For example, there is a potential to scratch an itch, flick a light switch in the dark, grasp my earlobe, and walk downstairs. Even these descriptions import so much from imagination that it is next to impossible to describe what it is like to carry out these activities in themselves. Indeed Merleau-Ponty held that 'the body is not an object, but rather a set of possibilities for action in a given environment' [61] (p. 295). It seems then that rather than these actions involving the interaction of objects in space, their objecthood is actualized upon "contact".

As an example, I was once a participant in a first-person experiment in which I was guided to walk with my eyes closed down some stairs. The experience was of the stairs and my feet co-actualising each other, rather than an interaction of pre-existing objects. The same applies to my hands coming together to touch each other. Two non-shaped phenomena change their proximity to each other in space, until they merge entirely and their shapes and solidity manifest. Again, it is only by filling in these phenomena with how I appear from the outside (including my own perspective of my body) that they are anything resembling a human body. A qualification to this is that the spatial locations of these phenomena maintain an isomorphism with my body parts' spatial locations as viewed from the outside. Calling the awareness of these experiences and these potentials for action 'bodily self-awareness' seems to have already brought in memory and imagination and in particular the perspective of others.

\section{The 'We'}

One ambiguity in the discussion so far has been what is meant by 'others'. When Harding claims that experiencing my body involves taking on the perspective of others, which others does he mean? If there are not actual others presently observing me, then this claim seems to be obviously false.

Harding qualifies that the others' 'consciousness of me is my self-consciousness actual or potential' [8] (p. 58). He also remarks that I still have a body for myself when I am on a desert island because I imagine how I would appear to others. I can become an other to myself by shifting my awareness to another centre:

To confer on myself a body is to confer on them a mind. No mind there, no body here. My self-awareness infects my environment with an awareness that is in no way fictitious: the mind with which I surround myself is as real as mine, for it is mine ... the fact is that I do know what this part of the world called my body looks like over there. Somebody is there watching me. That somebody is myself, yet another than myself. [8] (p. 58-59)

Imagination is one way in which I experience others, or at least potential others. It is also common within the phenomenological tradition to distinguish between the experience of concrete others and the experience of others in general, that is ' $\mathrm{We}^{\prime}$. In particular, Husserl, Heidegger and Merleau-Ponty hold that objects are perceived as being there for everyone (but these others do not need to be present ${ }^{18}$. As discussed below, Harding makes a similar point in his distinction between the private personal perspective and the 'mind' of humanity.

According to Heidegger, Others are encountered in equipment such as books and boats, which are given as ready-at-hand not just for oneself but for Others [45] (section 26). 
Heidegger qualifies his use of the term 'Others', which he uses interchangeably with 'They' (das Man) as follows:

By 'Others' we do not mean everyone else but me-those over against whom the "I" stands out. They are rather those from whom, for the most part, one does not distinguish oneself-those among whom one is too. [45] (section 26, p. 154)

In much the same vein is Merleau-Ponty's notion of the 'cultural world,' which is a subjectless, anonymous sediment of intentional actions which envelop cultural artefacts. Thus, for Heidegger and Merleau-Ponty, there is no problem of knowing others since their points of view and intentions are implicit in the perception of everyday objects. Furthermore, MerleauPonty states that it is the pre-personal and anonymous nature of perceptual consciousness that enables a slipping between perspectives, such that this perceptual consciousness inhabits both my body and that of the other simultaneously [31] (p. 412).

For Harding, I am not locked into my subjective centre, for at my centre I am nothing (I am looking out of a nothingness that has no personally identifying characteristics). In particular, the boundaries of the self are elastic and frequently expand (at least temporarily) to include others. When I identify with, act for and speak for my family, my town, my country or even my planet, I have temporarily shifted to a new centre that includes others. My viewpoint combines with that of others, so we share the viewpoint of our team, company, nation and so forth [14] (p. 113).

There are hence different levels of the 'We' for Harding. The highest human unit is humanity itself. The viewpoint of humanity resembles the We of Heidegger and MerleauPonty in some ways, although it also has significant differences [8] (p. 153-173). In particular for Harding, humanity is a concrete organism that is made up of all humans and all of their artifacts (over all of history). Individual humans are like the cells of the body of humanity. Artifacts are also an essential part of the body of humanity, just as dead matter makes up essential parts of the human body. This almost universally unrecognized organism can in fact be directly observed from an aeroplane and is given as a network of creepers across the landscape. The growth, development and decay of these creepers can be observed like any other living thing (see Figure 2).

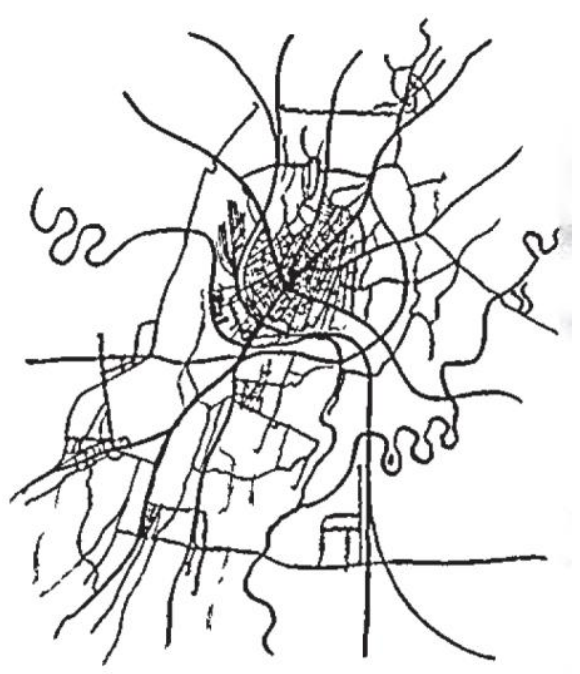

Figure 2. The Creeper (The body of humanity) [8] (p.154). Reproduced with permission of the Shollond Trust.

For Harding, individual humans and humanity are inseparable poles of human nature and one cannot exist without the other [8] (p. 164). As such the consciousness of humans is also the consciousness of humanity. The mind of humanity both transcends and is immanent in every individual perspective. While humanity transcends each individual perspective and their short lives, neither does humanity exist without them [8] (pp. 164, 171-172) ${ }^{19}$. 
According to Harding, I have then two ways of viewing the world, my private subjective view and the objective view of humanity, which combines all viewpoints upon a thing [8] (pp. 171-172). I can see railway lines as parallel rather than converging, a house as having four sides and an inside, rather than as just a façade, and my hand as smaller than my foot rather than larger as it subjectively appears (see Figure 3) (i.e., the area it takes up in my visual field $)^{20}$.

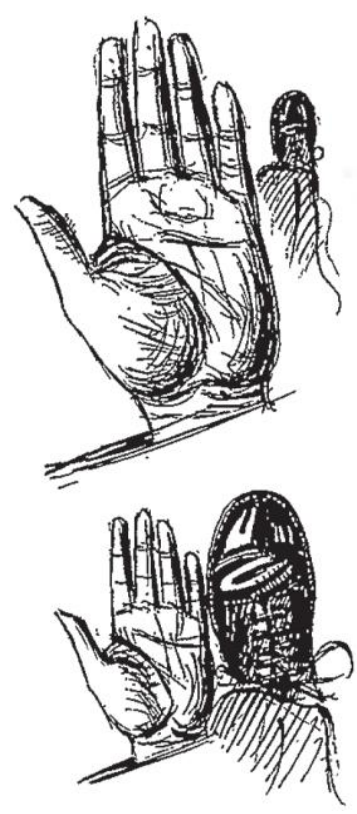

Figure 3. The subjective private view and the objective public view [8] (p. 171). Reproduced with permission of the Shollond Trust.

There is no mere personal or private human perspective, rather to be human at all is to have humanity immanent in oneself:

Long past is the time when I lived in a world of private realism and innocence of eye-the time when (as a baby of a few months) I was capable of noting that the face of a man, when seen in profile, is terribly mutilated. Now I have grown the myriad eyes of humanity, whereby I perceive my object from all angles and ranges; and my difficulty, as every draftsman knows, is to revert, when the occasion requires it, to my primitive binocular vision. In fact the wholly private view of things is an artificial abstraction: the union of my private view with others, to build humanity's view, is no external and theoretical construction-I am (in one of my aspects) humanity, and it is natural to me to see things his way. [8] (pp. 171-172)

This shows that when Harding claims that I cannot experience my body without others, these others do not need to be concretely present. I cannot help but to take the objective view of humanity upon things and to see them as things that possess all of their sides at once. Hence, even without others present, I will still see my body as a thing with hidden sides. In a sense, the viewpoints of all possible others are instantiated in me. For this reason, it is only with difficulty that I notice that from my first-perspective, I do not see my head and that visually-speaking I am looking out of emptiness.

Finally, Harding's system can be considered to be a version of panpsychist idealism, since the cosmos itself is constituted by interacting observers (though he intentionally avoids using idealist language). Hence 'the other' takes on a new meaning entirely in Harding's philosophy. All things are observers or aggregates of observers. Hence, even the sand underfoot, air particles, and trees will register my objecthood if only vaguely (and 
perhaps only as a mass of molecules rather than as a human body). I discuss Harding's panpsychism in more detail below.

\section{Embodiment}

Does Harding's approach ultimately disembody consciousness? What about the subject's being-in-the-world? It is going to depend upon what we mean by 'embodiment'. First, it is worth noting that Harding's phenomenological observations are in themselves metaphysically neutral or at least compatible with most metaphysical systems. Secondly, he rejects dualism, so consciousness is certainly not a substance that could exist without the body or world. Thirdly, his panpsychist metaphysics is compatible with the 4Es (Embodied, Embedded, Extended, Enacted) approach to cognition, particularly with versions which draw upon phenomenology [64-67]. Fourthly, however, it should be qualified that for Harding everything is psycho-physical-there are no mere physical things or processes [8] (p. 117). So, his view is certainly not 'embodiment' if by this term we mean the reduction of consciousness to causal-functional processes.

According to Harding, I am two-sided. I am equally my view out (my first-person perspective) and the view others have of me (the third-person perspective). In investigating the third-person perspective of me, Harding points out that how I appear to others depends upon the distance from which I am observed. For instance, from a few metres away, I appear as a person in the world. He then imagines how I appear to a travelling observer, who at all times makes careful note of how my appearance changes as they move. As the observer zooms in, I appear as face, then a patch of skin, then a blur. If my observer equips themselves with a microscope, the blur resolves into cells, then a single cell, then cell organelles. With further apparatus, including theoretical apparatus and imagination, closer still I appear (in a broad sense of appear) as molecules, atoms, and particles. As the observer approaches, they find that my thing-like nature breaks down and that at closer distances I am mostly empty space. I am apparently field-like rather than thing-like at near distances.

Scientists however cannot measure what I am like at zero distance. Measurement always requires some separation between the thing and the measuring device and/or observer. That is, it is still an open question as to what my fundamental nature is. This observation is closely related to the argument of Bertrand Russell [68] and Arthur Eddington [69] that science only ever discloses the causal/dispositional nature of things, not their intrinsic nature. We know what matter does, but not what it is in itself.

It is here that Harding makes an inference to the best explanation. In my own experience, I seem to be looking out of an empty space here that encompasses the given world. This is what it is like to be me at zero distance, right where I am. Hence, what I am at zero distance, or what I am fundamentally, is just an aware-space for things. This observation is supported by the third-person observer who also finds that I am progressively less thing-like at closer distances. That is, the two perspectives converge on the same answer. If this is correct, then awareness is at the ground of physical reality. This phenomenological method combines the first-person and third-person perspectives, and points to the answer that awareness is fundamental, hence providing a place for consciousness in the world. For Harding, then, this nothingness cannot be separated from the world because it is the noumenon of the phenomenal world [48] (p. 243). Another way of putting it is that it is the intrinsic nature of the physical world [48] (p. 108).

As well as how I appear at close and middle ranges, the travelling observer also carefully observes how I appear from further ranges. As they recede, they watch my human body shrink and become replaced by a city. For example, this is how I appear from an airplane. From further still I appear as a continent, then a planet, a star and then a galaxy. Harding concludes that these distal regional appearances also belong to me, they are layers of my greater body (see Figure 4). 


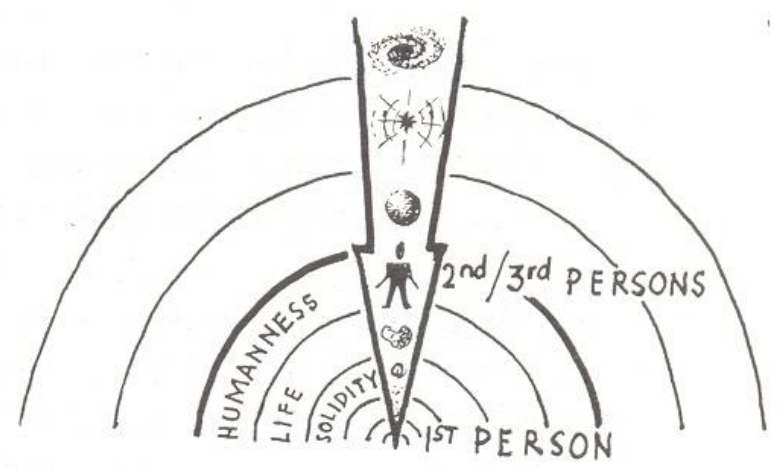

Figure 4. The layers of my appearances [48] (p. 263). Reproduced with permission of the Shollond Trust.

To the objection that I do not exist at these lower and higher levels because the human level has been left behind, Harding replies that this begs the question as to what I am by assuming that I am merely human. To only view me from preselected ranges would be as arbitrary as only viewing me from a couple of angles. To find out what I am, I should be viewed from all angles and all distances. All of these viewpoints, including my own, should be collected together before deciding what I am [8] (pp. 12-14).

As well as being the ground of physical reality, the central awareness is also 'embodied' in the sense that it cannot exist without its concentric outer layers such as particles, atoms, cells, organism, humanity and life (it is nothing in itself). I am just as much these peripheral regions as the central nothingness [8] (pp. 11-13). Furthermore, what I experience at any particular moment depends upon all of these levels and ultimately the whole [8] (pp. 38, 109).

One way of illustrating this interdependence of the levels is by showing that there is no hard line between my body and the environment. Harding argues that artifacts such as tools, my clothes and my house are just as much parts of my body (my 'outer organs') as my arms, legs, heart and kidneys (my 'inner organs') [8] (pp. 130-137). As my body is constituted by many dead parts there is no principled reason to exclude counting things that my body uses and depends upon as parts of my body ${ }^{21}$. My greater body also includes the town or city that I live in. For instance, farms, factories, roads and shops are extensions of my mouth and digestive system and the communal sewage system is an extension of my bowels. Ultimately, my greater body includes humanity, life, the Earth, the Sun and the Milky Way. I can also see this greater body and its levels as I look out, as represented in Figure 5.

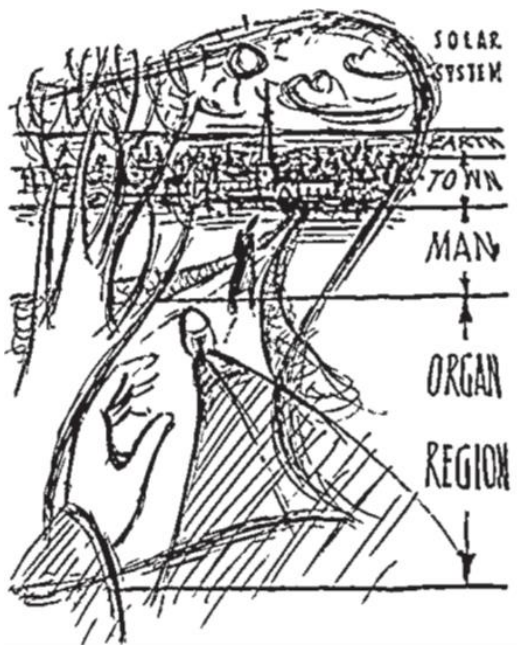

Figure 5. My view out including the levels of my greater body [8] (p. 10). Reproduced with permission of the Shollond Trust. 
That is, for Harding it is not just a case of being-in-the-world, but being-the-world. I do, of course, have a human body, but again, this is just how I appear from the middle range (say a few metres to a few hundred metres), whereas from millions of miles away, I will appear as a star. In a sense it could be said that we live our human lives (often to our detriment) by restricting our attention to the middle human regions, thus ignoring closer ranges and further ranges, for example the activity of cells (at the infra-human level) and that of the biosphere (at the supra-human level) and the essential role they play in maintaining our bodies and hence our human social world. Thus, Harding does maintain an embodied subjectivity, but in contrast to Merleau-Ponty and Sartre it includes all of the levels of nature as an indivisible, organic whole. That is, my embodiment is my emworldment.

In regard to intersubjectivity, for Harding my existence necessarily depends upon others. I am an empty centre emanating appearances to observers elsewhere. For close observers, I appear as atoms, molecules or cells. For middle range observers, I appear as a human or even a city. For distant observers, I appear as a planet, star or galaxy. I am nothing without observers reflecting these appearances at different ranges. I manifest in them. Neither am I anything without reflecting the appearances of others in me. Hence, others are not just essential for my human existence. They are essential at all levels of my being [8] (pp. 41-42, 115-119).

This shows that a form extended self-awareness is also possible either in imagination or by looking in a suitable reflecting surface. If I view myself in the mirror from a couple of feet away, I see my human face. That is how I appear from that distance. However, if a sufficiently large mirror were placed on the distant hills, it would reflect my city-face. Similarly, if the visible side of the moon was covered with a massive mirror, it would reflect my planetary-face and so forth [20] (pp. 49-50).

\section{Solipsism in Sartre and Harding}

I presented Harding's metaphysical views on intersubjectivity above but have so far not addressed his mystical claim that there is only one consciousness ${ }^{22}$. Does this view help or hinder in addressing the problem of solipsism? In fact, both Sartre and Harding held that consciousness is non-personal and that the ego is 'out there' in the world. While this is relevant for answering the challenge of solipsism, it also raises its own problems.

Sartre, in The Transcendence of the Ego approves of the statement by Rimbaud that: 'I is an other' [73] (p. 97). Both I and the other are in the world as objects of consciousness. Thus, in contrast to Descartes, there is no more certain knowledge of myself than of others, and if I doubt the existence of the other, I must also doubt the existence of myself. Since the I is in the world, it 'falls like other existences at the stroke of [the reduction]; and solipsism becomes unthinkable from the moment that the I no longer has privileged status' [73] (p. 104). That is, 'my I . . is no more certain for consciousness than the I of other men. It is only more intimate' [73].

Despite this, for Sartre my transcendent consciousness is ultimately separate to that of others' transcendent consciousnesses. Harding, on the other hand, is a mystic. For him, there is only one consciousness. Hence, he presents a novel mystical solution to the problem of other minds. 'My' consciousness is not sealed off from that of 'others' in separate, unknowable Cartesian cells. Rather, when I experience this anonymous consciousness, I know the innermost nature of all beings. Thus, like Descartes, I know my consciousness better than things; however, this consciousness is not a separate personal atomic substance, but the reality underlying all appearances. This is our common ground [8] (p. 108). Assessing Harding's arguments for mysticism would take us too far afield from the present topic ${ }^{23}$.

In later work, he proposes that this is a form of positive solipsism, in particular a solipsism by inclusion rather than exclusion of others [19] (p.331). This is not to imply, however, that there are no other perspectives. This is the one consciousness of all beings. This being said, that consciousness is anonymous, does not help us to escape the threat of solipsism, as the first-person experience does not provide evidence for any perspective other than my own. This is the problem with Sartre's response to solipsism in The Transcendence 
of the Ego as he later admits [30] (p. 318) and this problem also applies to Harding's posthierarchy work. For example, as the evidence of first-person experience provides one of Harding's primary reasons for believing in a single, indivisible, boundless consciousness (the 1st-Person Singular-e.g., [20]), it seems that I should also only believe in a single perspective, since I have never experienced any other perspectives. This is a potential weakness to this type of radical empiricism.

My own view is that it is virtually impossible to believe in solipsism because the mental lives of others are directly perceived in their every action [75]. So, when we take all of the content of first-person experience into account, we are driven away from solipsism rather than towards it. Hence, radical empiricism does not lead inevitably to solipsism.

While the latter Harding is certainly not a solipsist in the sense of denying others' perspectives. In The Hierarchy of Heaven and Earth, he holds that others are in fact metaphysically necessary to my existence [8]. The cosmic order is in fact constituted by observers reflecting each other's appearances. These observers are like nodes in a network. Without others to reflect, I would cease to exist altogether. The world that I experience is hence constituted by the "outer" side of numerous observers. The metaphysics of Harding's system in this book is therefore decidedly anti-solipsistic [9].

\section{The Primordial Social Interworld and the Concrete Experience of Others}

As discussed above, both Merleau-Ponty and Heidegger sidestep the issue of solipsism (and thus the question of how intersubjective communication is possible) by assuming at the outset a primordial interworld. For Merleau-Ponty and Heidegger, it is through our mutual being-in-the-world that we both share the same meaningful social space.

Sartre argues that such shared meanings do not provide a solution to how we experience others [30] (p. 316-318). As an example, he contends that Husserl's observation that things are given as intersubjectively available, only reveals the meaning of others, not concrete others themselves. The other remains in the abstract (a mere meaning or potential subject), it is not a particular concrete transcendental subject themselves-an other that is encountered as not being me.

Heidegger's account makes progress on Husserl's, according to Sartre, in that Heidegger realised that my relation with others should be at the level of being, not mere knowledge. My being-with-others is essential to my being human. However, Sartre also rejects Heidegger's account of being-with-others and by implication Merleau-Ponty's, because it is still too abstract and general [30] (pp. 330-336). Sartre claims that Heidegger's account of being-with-others amounts to an undifferentiated ' $\mathrm{We}^{\prime}$, it is not a reciprocal relation between self and other. Sartre asks 'how shall we be able to pass from there to the concrete experience of the Other in the world, as when from my window I see a man walking in the street?' [30] $(\mathrm{p}, 333)$ or to my concrete friendship with a particular other such as Pierre? The problem still remains of how we know the subjectivity of a particular concrete other (that is, the alterity or the otherness of the other). Hence, Sartre paves the way for his own solution in The Look in which the subjectivity of the particular other is encountered in my very being.

Merleau-Ponty acknowledges that his account also encounters this problem. He asks 'But is it indeed other people that we arrive at in this way? What we do in effect is iron out the I and the Thou in an experience shared by a plurality, thus introducing the impersonal into the heart of subjectivity and eliminating the individuality of perspectives. Yet have we not, in this general confusion, done away with the alter Ego as well as the Ego?' [31] (p. 414). That is, it seems that the personal level has been absorbed into the pre-personal, the reflective in the pre-reflective. For there to be true intersubjectivity there must be reciprocal recognition. That is, we must retain both horns of the dilemma, both an anonymous pre-aware world, and a reflective ego that differentiates self and other. As Merleau-Ponty admits, there is a marked difference between an other's experience of grief or anger and my experience of their grief or anger. For the other 'these situations are lived through, for me they are displayed' [31] (p. 415). Our perspectives cannot be superimposed, 
and even a shared project is experienced differently. However, if we reinstate a Cartesian cogito, the problem again becomes how does one I know another I?

One potential solution is that the 'tacit cogito', which for Merleau-Ponty is the bodysubject, simultaneously 'knows' the other in its bodily space, while maintaining its own awareness as a different body, with a different perspective upon the world. However, if the cogito is to remain merely tacit or sub-personal, there could be no mutual recognition of personal selves [76] (p. 200).

Thus Merleau-Ponty wishes to maintain a cogito but without re-establishing a Cartesian ego that is a 'hermetically sealed entity, locked away as it were in its own mind, fully present, unified, and self-certain' [77] (p. 503). It seems then that thought is required for distinguishing self and others, but this should not be a timeless res cogitans that is completely transparent to itself, with indubitable powers of self-knowledge regardless of the existence or non-existence of the world. This would seal the cogito in the inner citadel of its own self-knowledge, thus establishing an unbridgeable gap between self and other, and self and world.

For Merleau-Ponty, it is language which allows for the mutual recognition between selves, and is in fact central to the creation of a reflective self. According to Merleau-Ponty, in dialogue a common world is reciprocally created which is the ground for both our thoughts:

In the present dialogue, I am freed from myself, for the other person's thoughts are certainly his; they are not of my making, though I do grasp them the moment they come into being, or even anticipate them. And indeed, the objection which my interlocuter raises to what I saw draws from me thoughts which I had no idea I possessed, so that at the same time that I lend him thoughts, he reciprocates by making me think too. It is only retrospectively, when I have withdrawn from the dialogue and am recalling it that I am able to reintegrate it into my life and make of it an episode in my private history. [31] (p. 413)

Harding suggests a relevant first-person experiment for investigating interpersonal dialogue, which provides insights into both the oneness and the multiplicity in verbal dialogue [56] (p. 163). When talking with another, if we both close our eyes and listen to our voices as they arise, we will notice that they manifest within a background silence. During the conversation both our voices are different. They have different tones, pitch and so forth but they both occur in the same silence. Since this silence or space has no personal identity, it is just as much the other's as my own. However, each voice is unique so there is a genuine sense of individuality arising in the same space. Each voice is associated with either myself or the other. I can also intentionally control one of those voices. Sometimes though, I really do not know what I will say next and listen to hear what 'my voice' will say with just as much curiosity as what 'your voice' will say. At a deeper level then (particularly in terms of sensory experience), both voices can be considered mine.

\section{Harding on Personal Relationships}

According for Harding, my mind is not trapped in a head-box here, but at large in the world. My desires, likes and love reside not here in a separate mind, but out there in the world attached to their objects. 'Every object comes fully clothed with emotional significance' [8] (p. 74). He hence thoroughly rejects any ontological duality between the mental and the physical, the internal and the external. He agrees then with William James that 'Every thing or quality felt, is felt in outer space ... The very first sensation which an infant gets is for him the outer universe' [78] (pp. 15-16), cited [8] (p. 74). To try to divide mind from the physical world is an artificial abstraction.

The question thus becomes how is the 'I' differentiated from the world and others in first-person experience? For Harding, the first main source of my sense of separation from others comes from projecting others as being located at a distance from me. According to Harding, things are presented to me right where I am, but are projected as being over there. This apparent distance gives a sense of otherness to perceived things and people. Ultimately, however, the distance between myself as observer and others is a kind of quasi 
dimension because when I try to measure the distance between myself and an object from the first-person perspective my ruler shrinks to a point. Nothing actually comes between me and others [8] (pp. 19-21).

The second main source of the sense of separation is taking on others' perspectives on myself. He admits that there is often a sense of self-feeling which seems to come from a contrast of bodily sensations such as eye-sensations, forehead sensations, etc. with objects. In this way, 'I' am separated from others; however, to place these in a body, I must shift my centre and view myself from the outside [8] (p. 64).

Hence, there is no question of a private bodily state. To experience the pain as being in my body is to already have taken on the perspective of the other. That is, since others see my body as separate from the world, when I take on their perspective, the pain seemingly becomes my own private pain, rather than a state of my world.

Harding holds that by imagining that the face in the mirror resides in the middle of my world - that is playing the face game-a pseudo-separation is created between 'me' and 'others'. The common sense understanding of interpersonal relations is that we meet 'face-to-face'. This suggests that persons are spatially separate things in the world, with separate subjective interiorities behind their faces. Indeed, the term 'person' is derived from 'persona', the Latin name for the masks that actors would use in the ancient Greek theatre to portray their characters. To be a person then is to wear a mask and play a particular role or game. From the first-person perspective, the conception that interpersonal relationships consist of a confrontation between things is a delusion. Our acceptance of this everyday assumption is to take a third-person perspective on the relationship. However, from firstperson lived perspective we are never 'face-to-face'. It is not a symmetrical relationship, but asymmetrical. The lived social experience is of being 'face-to-no-face'. Or to put it another way, during social communication, we 'trade faces' [39] (p. 16).

In seeing that one is not really separate from others, one does not stop playing the face game, rather one becomes aware that it is a game. Harding's proposal is not to disclaim knowledge of others' perspectives of myself by reverting back to an infant's perspective, but rather to be aware that this is only my peripheral nature. It is peripherally true of me but not centrally true [19] (p. 63), [56] (pp. 157, 162, 171-172). My original nature is openness to others and the world. Acting as if I am merely a thing, that excludes other things, is a game. It is a useful social fiction to some extent, like money, ownership, social status and countries. Like all social fictions there are many benefits to acting as if they are real (this also gives them reality at the social level). Yet coming to believe in these social fictions (particularly coming to identify completely with them), as if they were the only reality, is extremely damaging, as evidenced by greed, hatred, prejudice and war.

To use terminology coined by Richard Lang, we can distinguish then three general stages in the development of human consciousness [34] (p. 74):

(1) Unconscious first-personhood. This is the stage of the infant who is completely open to the world, though unconsciously so. There is no reflective awareness that they are an object in the world. For example, babies do not recognise themselves in a mirror before 18 months [35]. Infants below 3.5 months old also do not yet possess 'object permanence', that is an awareness that objects continue to exist when they are out of sight or occluded (e.g., [79]). Infants, however, do show an impressive ability for non-conceptual social cognition, such as perceiving others' emotions (5-7 months), seeing actions as intentional and participating in joint attention (9 months) [75]. There is also evidence that there is a matching between the infant's bodily proprioception and the visual experience of the same body part of others, allowing newborns to flexibly imitate others' actions such as tongue protruding [50]. This suggests that newborns are not the solipsists they were portrayed as by Piaget. However, the innate ability to imitate is still controversial in the field [80-82 $]^{24}$.

(2) Conscious third-personhood. The awareness of how one appears to others and the explicit understanding that they have hidden mental states different to your own begins in early childhood [87]. By adulthood, one develops a strong sense of one's third-personhood and in most cases comes to almost completely identify with it. However, the sense of one's 
non-personal spacious awareness is never completely lost. Note how one can 'take a break from being a person' when engaging in absorbing, usually non-social, activities. Alcohol is also used by many to short-circuit the person-building processes and to recover some of the spontaneity and openness of their childhood. This stage is marked by the development of sophisticated conceptual schemas about oneself and the world. For instance, one learns that objects continue to exist when not being looked at, and that one is just a thing in the world like everyone else, and one develops a complex and unique personal identity and self-story.

(3) Conscious first-personhood. As this stage has not been researched to my knowledge, these remarks are somewhat anecdotal (for discussion and some first-person reports, see [34]). The experience of practicing conscious first-personhood is likely to vary between individuals, so what follows are descriptions of possible experiences of the practice of 'headlessness' not prescriptions of what should be experienced. Like all of the claims made in this article, they should be tested out for oneself. In this stage, one is consciously aware that for oneself you are not a thing in the world, but the world is in you. You do not confront others, but disappear in favour of them. At the same time, you are aware of your third-personhood and can shift between your first-person and third-person identities. One finds that human relationships continue much as before, but when one is aware of one's 'facelessness' one tends to be more spontaneous. One does not need to 'maintain face' or 'put up a front'. Somewhat paradoxically, one's personal life seems to go much smoother and be more productive when one gives up trying to 'make something of oneself' and to 'be somebody'. Viktor Frankl advised that happiness is an outcome of pursuing meaningful activities in the world or loving others. To intentionally aim for happiness is self-defeating [88] (p. 87). Rather happiness comes from transcending the self. Frankl observed:

Ultimately man can actualize himself only by fulfilling a meaning out there in the world rather than within himself so that self-actualization becomes in effect "selftranscendence". Being human means relating and being directed to something other than oneself. [88] (p. 86) ${ }^{25}$

Finding meaning in the world and others seems to require openness to the world and others. Hence, conscious first-person openness is a natural complement to such a world-focused/other-focused outlook. Of course, being consciously open to the world, does not mean that one does not also often feel like one is a separate person. One is aware of being space for others and one's own sense of personhood. When one is conscious of their first-person openness, the sense of being a person may be less central. It may shift to the background of consciousness or hardly be evident at all. Ironically, one is more themselves when they lose themselves in the present situation. However, in contrast to some spiritual traditions, the goal of this practice is not to eradicate the sense of self. The self is a valuable aspect of the given world. One's unique third-person identity is how one is expressed in others and makes human relationships possible. One's third-personhood is reflected back both verbally and non-verbally in every social exchange. To lose awareness of this completely would be to lose my humanity. This identity may be even more valued now that one is no longer merely it. In fact, given that one's third-person identity manifests differently in every observer ('Brentyn' is a cloud of appearances), properly speaking one has numerous third-person identities. In terms of lived personal relationships, one is now aware of being space for others and that others are space for oneself (even if others do not notice this). However, one still knows that they are face-to-face with others from a third-person perspective and so continues to wipe their mouth with a napkin after dinner! One is aware how things move through consciousness when they are walking and how things seem to change size as one approaches. Yet one also knows and makes use of common-sense assumptions, such as objects have a fixed size, and that for others, I am an object moving through a static landscape [19] (p. 63). 


\section{Conclusions}

In this article, I have presented a critical dialogue between Harding, Sartre and Merleau-Ponty on the body and intersubjectivity. Out of this interplay, there emerged a number of tensions and disagreements between these philosophers, but also much agreement. It became apparent that the first-person experience of our own body presupposes the perspective of others. There is a compatibility between Harding's first-person experiments with vision and touch with Merleau-Ponty's claim that the body-subject is pre-reflectively open to the world. That is, the conscious experience dovetails with the pre-aware openness of the body-subject.

A major divide emerged in the foregoing discussion between Harding's first-person approach and Merleau-Ponty's embodied subject. The main difference between MerleauPonty and Harding seems to be that the former merges the first- and third-person perspectives, mind and body into an ambiguous unity in the lived body, while the latter keeps them distinct. For Merleau-Ponty, the subject could never look out of nothingness. My body is my perspective. One specific difference between Merleau-Ponty's and Harding's approach is that Merleau-Ponty places an emphasis upon acquired meanings while Harding places an emphasis upon perception. Taken as a unity of meaning and perception, my body does seem to be given as an ambiguous blend of subject and object. This seems to be the everyday experience of being human. However, according to Harding, this meaning-experience of being a mere human subject in the world is an outcome of development (a product of socialization). That is, we learn to map the third-person perspective onto the sensory experience of the first-person. It is by confusing the first-person and third-person perspectives that obscures my first-person perspective in which the world is in me. Nevertheless, I need both perspectives. For Harding, I am simultaneously my view out and others' views in. The problem as he sees it is that we overlook our own first-person view out. For Merleau-Ponty, it would seem that this ambiguity is inherent to the body-subject; however, I suggest that his insights can be partly reconciled with that of Harding by including a developmental dimension in the meaning-experience of my body.

In Harding's philosophy, self-awareness comes in at least three forms; all of which also amount to an awareness of others. Firstly, there is my awareness of others' 'view in' to my centre (my body). To be aware of my body is to be aware of how I appear from varying distances to others. Hence, self-awareness of my body involves other-awareness.

A second form of self-awareness is of my 'view out' out of centre (my mind). Because I am radically open to the world, my awareness of others is also a form of self-awareness. At zero distance, I have no personally identifying characteristics. As nothing here in myself, I am absolutely unified with others [12] (p. 60), [56] (pp. 48, 65). As Harding states: 'Paradoxically, just because this Space is absolutely unlike and absolutely uncontaminated by its contents, it is absolutely identified with them. I do not believe this, I see it. The Space is the things that occupy it' [12] (p. 60). When I see an other, I am that other. Their face is my face. The same can also be said for the other senses. There is no separate 'me' hearing their voice, rather their voice is me. Feeling their hand is to bodily become their hand. Consistent with contemplative traditions such as Zen Buddhism and the Advaita Vedanta, there is no duality of subject and object [18] (Section 7). In fact, my view out is completely constituted by the "outer" manifestations of others in me. Hence, awareness of my own first-person perspective is constituted by my awareness of others.

A third form of self-awareness is of myself here as a central emptiness. As this unbounded emptiness has no individuating characteristics (and is not even located in space), Harding argues from the identity of indiscernibles that it is identical with the innermost nature of every observer [8] (p. 106). Hence, this self-awareness is not unique to me (it is not personal), but common to all observers. Harding refers to my "relationship" with others as a 'double identity' [56] (p. 139). I am identical with both their appearance as a person and their underlying reality as aware-emptiness. It seems then that overall, for Harding, we can say that all self-awareness = other awareness, and vice versa. 
An objection to Harding's first-person observations is the apparent implication that the other is just a picture in consciousness, e.g., [56] $(p, 171)^{26}$. How can I relate to others if the direct experience is that they are flat cardboard cut outs? Harding denies this charge because consciousness is non-personal and not in anything (including space), so it cannot be distinguished from the consciousness of the other-it is their consciousness [20] (p. 56, 63), [56] (p. 171). Hence the other is certainly not unconscious on his view. Even so, what of the unique perspective of the other? I mentioned the unique voice of the other in interpersonal dialogue in Section 8.

His observations would also naturally benefit by incorporation of observations of phenomenologists. In particular, the direct experience is that I see the intentions in others' bodily movements and see the emotion in others' faces and hear it in their voices [75]. This would naturally combine with Harding's notion in The Hierarchy of Heaven and Earth that all things are two-sided - there is always a view in and a view out. As the view in and the view out are two sides of the same coin, it would make sense that some of the contents of other's perspectives (their mind) could be directly perceived in their bodily expressions. Furthermore, as qualities, value and meaning belong to the perceived universe [20] (pp. 60-61), [19] (Chapter 9), [56] (p. 158), it is natural to hold that others' mental lives would also be partially given in perceptual experience.

It also became apparent throughout the discussion that both a pre-reflective social interworld and reflective awareness are required to account for intersubjective relations between self and other. Without an interworld, there seems to be no possibility of knowing, or communicating with others. For Merleau-Ponty, I 'know' others through my body. Sartre, however, makes an important point that a pre-aware primordial ' $W e^{\prime}$ does little in accounting for the concrete experience of self-other relations. For Sartre, it is in The Look that I directly encounter the other's subjectivity and freedom. However, since this encounter is incompatible with my own subjectivity and freedom (i.e., it transforms me into an object-for-others) this relation is based upon an intrinsic conflict. Though conflict is certainly an aspect of intersubjective relations, it seems difficult to explain positive nonconflicting relations on this basis. It is here again that Merleau-Ponty provides positive examples of concrete intersubjective relations in the form of speech and gesture.

While language provides an account for how self and other are differentiated in dialogue, Harding and Sartre further contributed to distinguishing self and others by showing how we take on others' perspectives upon ourselves. Harding gives a specific example, in terms of the development of the face game. That is, by building a face here, I establish an illusory separation between self and others, which is a major source of conflict. Both accounts seem to play essential roles in distinguishing self and others in interpersonal relationships.

Despite the similarities between Harding and Sartre's descriptions of consciousness as nothingness, they come to opposite conclusions. In particular, Sartre proposes that consciousness is negating - it separates me from the world and others, while for Harding, my emptiness is a form of radical openness to the world. As this void I disappear in favour of others. Thus, unlike Sartre, the relation between myself and others is not one of confrontation. In fact, confrontation is a kind of collective hallucination [39]. Harding suggests that conscious first-personhood is a practical means of breaking down the delusion of separation, thereby supporting compassion and intimacy.

In this article, I endeavoured to show that Douglas Harding offers useful insights in phenomenological investigations of the body, self and others. In comparing and contrasting Harding, Sartre and Merleau-Ponty, the position of each theorist shows their own unique advantages and limitations and each benefits from a dialogue with the other. On the whole, our relations with others seem to rely upon a balanced tension between aware and pre-aware relations, conflict and communication, solipsistic withdrawal into one's self and dissolution of self-other boundaries. Rather than requiring a resolution, these tensions may simply be an inherent aspect of lived intersubjective relations.

Funding: This research was supported by a Humboldt Postdoctoral Research Fellowship, The Alexander von Humboldt Foundation. 
Acknowledgments: This article began its life as an honours thesis completed at the University of Queensland in 2009. I am grateful to Aurelia Armstrong and Michelle Boulous Walker for their feedback on the thesis.

Conflicts of Interest: The author declares no conflict of interest.

\section{Notes}

1 I take 'pre-reflective' experience to mean a form of first-order, implicit experience in contrast to second-order, explicit experience [7] (Section 1). A pre-reflective experience can be understood as a kind of non-objectified, fringe or background experience that is not in the focus of attention. Here I use 'pre-reflective' and 'pre-aware' interchangeably.

2 Douglas Harding's main philosophical work, The Hierarchy of Heaven and Earth [8]), took eight years to write and can be considered a synthesis of science and mysticism. This magnum opus remains almost entirely unexplored by philosophers (though see Ramm [9]). Harding published a precis of The Hierarchy of Heaven and Earth with Faber and Faber in 1952 [10], which was reviewed in Mind at the time of its publication [11]. Within the context of academic philosophy, an excerpt from On Having No Head [12] appeared in The Mind's I [13], and part 1 of the précis of The Hierarchy of Heaven and Earth was recently reprinted in Mind and Matter [14].

3 I have included 'as an essential component' in this definition to take into account that phenomenological methods such as philosophical phenomenology are philosophical endeavours, not just descriptions of experience [15].

$4 \quad$ Natalie Depraz, Francisco Varela and Pierre Vermersch [32] identify three interlinked cyclic phases in taking on the phenomenological attitude: (1) Suspension of habitual thoughts and judgments; (2) A redirection of attention to the lived qualities of experience; and (3) Receptiveness to experience ('letting-go'). See also Lutz and Thompson [33] (pp. 37-38).

5 For examples of the pointing experiment see Ramm [16] (p. 153), [17] (p. 10), [18] (p. 8).

6 For versions of the holding your ears experiment see Harding [19] (pp. 70-71), Lang [34] (p. 80).

7 We can distinguish between an aware-void, in which the awareness is intrinsic to the void, and an awareness that is emanating from or directed outwards from the void. I will remain neutral here about which is the phenomenologically correct description.

8 For discussions see: [40-42].

9 An anonymous reviewer objected to the possibility of a phenomenology of nonduality on the grounds that the phenomenological method could not be carried out without a distinction between subject and object. I agree with this point when it comes to Husserl. As Stone and Zahavi put it 'The aim of phenomenology is precisely not to investigate either the subject or the object, either the mind or the world, but to investigate both in their interrelation or correlation' [15] (p. 173). This seems to rule out a Husserlian phenomenology of subject-object nonduality. In any case, Harding's approach has more in common with meditation methods than Husserlian phenomenology. This being said, apart from being experiential, Harding's methods also have little in common with contemporary passive approaches to meditation that encourage non-judgemental, bare attention to whatever arises ('mindfulness') (see Bodhi [43] for a discussion of contemporary and traditional uses of this term).

10 The strong influence of Heidegger on Merleau-Ponty does not however imply that Merleau-Ponty saw himself as turning his back on Husserl. Merleau-Ponty studied Husserl's later works and unpublished works before completing The Phenomenology of Perception [47] (p. 25). In the preface to this work, he was also clear on his view of the influence of Husserl on Heidegger's work: 'The whole of Sein und Zeit springs from an indication given by Husserl and amounts to no more than an explicit account of the 'natürlicher Weltbegriff' or the 'Lebenswelt' which Husserl, towards the end of his life, identified as the central theme of phenomenology' [31] (viii).

11 Gallagher and Meltzoff [50] review evidence that newborns will match an adult's tongue protrusion and head movement, even after a delay, which they argue shows imitation rather than a reflexive response. However, these findings are controversial in the literature. See note 24 below.

12 Simone de Beauvoir defends Sartre, claiming that Merleau-Ponty attacks a pseudo-Sartreanism and gives too much emphasis to The Look [51]. Elaborating upon de Beauvoir's criticisms, Monika Langer [52] argues that the 'interworld' for Sartre is the 'flesh'. In sexual desire the for-itself simultaneously experiences both its carnal bodily presence and that of the other. In desire, the self and other are mutually present in their embodiment. In fact, sexuality for Sartre is the basic foundation on which human relationships are built. In desire, the for-itself loses its lightness and transparency and becomes heavy and opaque, it is engulfed in its body. In particular, in the caress, which is the incarnation of desire, we are mutually born as flesh. Thus, through the caress, we are mutually embodied. When this reciprocity breaks down, however, such that I desire to dominate the other as a mere object, or I desire to be dominated as a mere object, then it results, respectively, in sadism or masochism. Furthermore, in the desiring of objects, I experience the flesh of objects and the world, as encountered through my incarnate body. Thus, like Merleau-Ponty, for Sartre the body is an interworld between self and other. This being said, the Sartrean interworld is severely limited. For Merleau-Ponty on the flesh see Maurice Merleau-Ponty's The Visible and the Invisible [53]. For a contrast of Sartre's and Merleau-Ponty's views on the caress and flesh see Glen Mazis [54]. 
For a discussion of this issue see Harding's article 'On Having a Head' [55] (pp. 161-172). Harding points out that if this is a head here, it is very unusual in that it is transparent and contains everything including other people, the hills, the sky. It is more like a cosmic head rather than an ordinary head.

For examples of the eyes closed experiment see Harding [12] (p. 58), [56] (pp. 57-60).

See Mary Warnock [57] (p. 81).

16 This experiment is based on the touch experiment by Steve Munroe, https://www.headless.org/experiments/touch.htm (accessed on 27 November 2021)

17 For further discussion of this point see Giles [58] (pp. 107-108).

18 Zahavi [62] shows that Husserl distinguished between multiple types of intersubjectivity including: (1) concrete transcendental intersubjectivity (for example, the concrete experience of another's subjectivity in both experiencing the same object) and (2) open intersubjectivity (for example, the experience that the same object can be experienced for potential subjects). The latter is always present and the former also presupposes the latter.

19 Does humanity have its own conscious mind over and above that of its individuals? Is it a self-conscious entity? How unified is its 'mind'? Harding prefers to avoid giving a direct answer to these questions, but rather notes the intelligent behaviour of the creeper as it grows across the landscape eating resources, crossing rivers and growing towns and cities [8] (pp. 161-163). He does also admit that its warring states and its destruction of nature suggest that the organism of humanity is somewhat sick and its mind dissociated [8] (pp. 163, 167). This seems to leave open whether humanity has its own unique sense of self beyond that of the individuals that compose it. However, he seems to rule out this possibility in the following passage: 'Humanity alone and apart from men, Humanity as a mind or consciousness which is more than the common mind that is in them, Humanity that is not at once wholly immanent and transcendent, is a monstrous superstition, richly deserving the contempt of common sense' [8] (p. 164). On the other hand, if we think of the 'mind' of humanity in terms of its ever-developing knowledge, this clearly transcends that of any one individual, "stored" as it is across billions of brains, numerous books, not to mention digital devices and the internet.

20 'Objective' and 'subjective' cannot be separated for Harding. There is no objectivity without subjectivity. The objective is constructed by combining subjective views together and abstracting from them. Objectivity is a form of intersubjectivity. This resembles Husserl's approach in which the experience of the objective is grounded in the experience of intersubjectivity $[62,63]$.

Here Harding seems to anticipate 'the extended mind hypothesis' popular in contemporary cognitive science [70]. Harding argued that there is no clear boundary between the human body and artifacts in his book An Unconventional Portrait of Yourself, which was completed in 1941 [71], and also in The Hierarchy of Heaven and Earth [10].

By mysticism, what Aldous Huxley [72] refers to as the 'Perennial Philosophy', I mean the mystical claim common to many religious traditions that: (a) the innermost reality of all beings transcends space, time and causation and (b) this fundamental reality is directly experienceable by humans.

23 For arguments in favour of the Perennial Philosophy see Miri Albahari [74].

24 This prominent body of research indicates that newborns are capable of imitating others' actions, such as tongue protruding and mouth opening despite not being able to see the body part they are moving (invisible imitation) $[83,84]$. This suggests that there is an innate cross modality sensory-motor connection between one's own bodily actions and others' bodily actions. This research has been taken by philosophers as evidence of a form of innate embodied self-other awareness [50,65,85]. These findings have recently been questioned due to failures to replicate and the possibility of other confounding factors [80-82]. For example, infants spontaneously make facial movements and increased tongue protruding in response to any increase in arousal [86]. A comprehensive longitudinal study of 106 infants found that newborns' behaviours, such as tongue protrusion, did not occur significantly more in response to matching models than 11 control models (e.g., mouth opening, face smiling, face frowning, finger protrusion). Jones [80] only found evidence of invisible imitation of tongue protrusion and hand on head at 16-18 months. This outwards focus has also been found to be more effective in a recent study in which students reported feeling happier when trying to make others happy rather than themselves [89].

26 For a discussion see David Lang's article Figuring out the Unfiguroutable in Lang [34] (pp. 127-129).

\section{References}

1. Descartes, R. Meditations and Other Metaphysical Writings; Clarke, D.M., Ed.; Translator; Penguin Books: London, UK, 2003.

2. Wittgenstein, L. Philosophical Investigations; Blackwell: Oxford, UK, 1953.

3. Zahavi, D. Husserl's Phenomenology of the Body. Études Phénoménologiques 1994, 10, 63-84. [CrossRef]

4. Smith, D.W. Phenomenology. In The Stanford Encyclopedia of Philosophy; Zalta, E.N., Ed. Available online: https:// plato.stanford. edu/archives/sum2018/entries/phenomenology/ (accessed on 15 September 2021).

5. Husserl, E. Cartesian Meditations: An Introduction to Phenomenology; Martinus Nijhoff: The Hague, The Netherlands, 1960.

6. Husserl, E. The Crisis of European Sciences and Transcendental Phenomenology: An Introduction to Phenomenological Philosophy; Northwestern University Press: Evanston, IL, USA, 1970. 
7. Gallagher, S.; Zahavi, D. Phenomenological Approaches to Self-Consciousness. In The Stanford Encyclopedia of Philosophy; Zalta, E.N., Ed. Available online: https:/ / plato.stanford.edu/archives/spr2021/entries/self-consciousness-phenomenological/ (accessed on 22 November 2021).

8. Harding, D.E. The Hierarchy of Heaven and Earth: A New Diagram of Man in the Universe, digital ed.; The Shollond Trust: London, UK, 2011.

9. Ramm, B.J. Panpsychism and the First-Person Perspective: The Case for Panpsychist Idealism. Mind Matter 2021, 19, 75-106.

10. Harding, D.E. The Hierarchy of Heaven and Earth: A New Diagram of Man in the Universe, abridged ed.; University Presses of Florida: Gainesville, FL, USA, 1979.

11. Scrutton, M. The Hierarchy of Heaven and Earth. Mind 1954, 63, 113-114. [CrossRef]

12. Harding, D.E. On Having No Head: Zen and the Rediscovery of the Obvious; The Shollond Trust: London, UK, 2001.

13. Hofstadter, D.R.; Dennett, D.C. The Mind's I: Fantasies and Reflections on Self and Soul; Basic Books: New York, NY, USA, 1981.

14. Harding, D.E. The Hierarchy of Heaven and Earth. Mind Matter 2021, 19, 107-129.

15. Stone, O.; Zahavi, D. Phenomenology and Mindfulness. J. Conscious. Stud. 2021, 28, 158-185.

16. Ramm, B.J. Self-Experience. J. Conscious. Stud. 2017, 24, 142-166.

17. Ramm, B.J. Pure Awareness Experience. Inquiry 2019, 1-23. [CrossRef]

18. Ramm, B.J. The Technology of Awakening: Experiments in Zen Phenomenology. Religions 2021, 12, 192. [CrossRef]

19. Harding, D.E. The Trial of the Man Who Said he was God; The Shollond Trust: London, UK, 2002.

20. Harding, D.E. The Science of the 1st-Person: It's Principles, Practice and Potential; The Shollond Trust: London, UK, 2001.

21. Harding, D.E. Religions of the World: A Handbook for the Open-Minded; Head Exchange Press: London, UK, 1995.

22. Edie, J.M. William James and Phenomenology; Indiana University Press: Bloomington, IN, USA, 1987.

23. Fisette, D. Phenomenology and Phenomenalism: Ernst Mach and the Genesis of Husserl's phenomenology. Axiomathes 2011, 22, 53-74. [CrossRef]

24. Albertazzi, L. Handbook of Experimental Phenomenology: Visual Perception of Shape, Space and Appearance; John Wiley \& Sons: Chichester, UK, 2013.

25. Albertazzi, L. Experimental Phenomenology for Consciousness. Psychol. Conscious. Theory Res. Pract. 2021, 8, 116-142. [CrossRef]

26. Ramm, B.J. First-Person Experiments: A Characterisation and Defence. Rev. Philos. Psychol. 2018, 9, 449-467. [CrossRef]

27. Verstegen, I. Mona Lisa's smile: The Place of Experimental Phenomenology within Gestalt Theory. Gestalt Theory 2005, 27, 91-106.

28. Vicario, G.B. On Experimental Phenomenology. Adv. Psychol. 1993, 99, 197-219.

29. Mach, E. The Analysis of Sensations-Anti-Metaphysical. Monist 1890, 1, 48-68. [CrossRef]

30. Sartre, J.-P. Being and Nothingness: An Essay on Phenomenological Ontology; Philosophical Library: New York, NY, USA, 1956.

31. Merleau-Ponty, M. Phenomenology of Perception; Routledge Classics: London, UK, 2002.

32. Depraz, N.; Varela, F.; Vermersch, P. The Gesture of Awareness: An Account of its Structural Dynamics. In Investigating Phenomenal Consciousness; Velmans, M., Ed.; John Benjamins Press: Amsterdam, The Netherlands, 2000; pp. 121-136.

33. Lutz, A.; Thompson, E. Neurophenomenology: Integrating Subjective Experience and Brain Dynamics in the Neuroscience of Consciousness. J. Conscious. Stud. 2003, 10, 31-52.

34. Lang, R. Seeing Who You Really Are: A Modern Guide to Your True Identity, revised ed.; The Shollond Trust: London, UK, 2012.

35. Amsterdam, B. Mirror Self-Image Reactions Before Age Two. Dev. Psychobiol. J. Int. Soc. Dev. Psychobiol. 1972, 5, $297-305$. [CrossRef] [PubMed]

36. Anderson, J.R.; Gallup, G.G. Mirror Self-Recognition: A Review and Critique of Attempts to Promote and Engineer SelfRecognition in Primates. Primates 2015, 56, 317-326. [CrossRef]

37. Gallup, G.G. Chimpanzees: Self-Recognition. Science 1970, 167, 86-87. [CrossRef]

38. Reiss, D.; Marino, L. Mirror Self-Recognition in the Bottlenose Dolphin: A Case of Cognitive Convergence. Proc. Natl. Acad. Sci. USA 2001, 98, 5937-5942. [CrossRef] [PubMed]

39. Harding, D.E. “Confrontation": The Game People Play. Transpers. Trans. Anal. 1986, 16, 99-109. [CrossRef]

40. Vasseleu, C. Textures of Light: Vision and Touch in Irigaray, Levinas, and Merleau-Ponty; Routledge: London, UK; New York, NY, USA, 1998; p. 157.

41. Jay, M. Downcast Eyes: The Denigration of Vision in Twentieth Century French Thought; University of California Press: Berkeley, CA, USA, 1994.

42. Schutte, O. Irigaray on the Problem of Subjectivity. Hypatia 1991, 6, 64-76. [CrossRef]

43. Bodhi, B. What Does Mindfulness Really Mean? A Canonical Perspective. Contemp. Buddhism 2011, 12, 19-39. [CrossRef]

44. Harding, D.E. The Face Game. Trans. Anal. Bull. 1967, 6, 40-52. [CrossRef]

45. Heidegger, M. Being and Time; Harper: New York, NY, USA, 1962.

46. Moran, D. What is the Phenomenological Approach? Revisiting Intentional Explication. Phenomenol. Mind 2018, 15, 72-90.

47. Merleau-ponty, M. Maurice Merleau-Ponty: Basic Writings; Routledge: London, UK, 2004.

48. Harding, D.E. Head off Stress; The Shollond Trust: London, UK, 1999.

49. Kwant, R.G. The Phenomenological Philosophy of Merleau-Ponty; Duquesne University Press: Pittsburgh, PA, USA, 1963.

50. Gallagher, S.; Meltzoff, A.N. The Earliest Sense of Self and Others: Merleau-Ponty and recent developmental studies. Philos. Psychol. 1996, 9, 211-233. [CrossRef] [PubMed] 
51. De Beauvoir, S. Merleau-Ponty and Pseudo-Sartreanism. In The Debate between Sartre and Merleau-Ponty; Stewart, J., Ed.; Northwestern University Press: Evanston, IL, USA, 1998; pp. 448-491.

52. Langer, M. Sartre and Merleau-Ponty: A Reappraisal. In The Debate between Sartre and Merleau-Ponty; Stewart, J., Ed.; Northwestern University Press: Evanston, IL, USA, 1998.

53. Merleau-Ponty, M. The Visible and the Invisible; Northwestern University Press: Evanston, IL, USA, 1968.

54. Mazis, G.A. Touch and Vision: Rethinking with Merleau-Ponty Sartre on the Caress. In The Debate between Sartre and Merleau-Ponty; Stewart, J., Ed.; Northwestern University Press: Evanston, IL, USA, 1998; pp. 144-153.

55. Harding, D.E. Look for Yourself: The Science and Art of Self-Realisation; Head Exchange Press: London, UK, 1996.

56. Harding, D.E. Face to No-Face: Rediscovering our Original Nature; InnerDirections Publishing: Carlsbad, CA, USA, 2000.

57. Warnock, M. The Philosophy of Sartre; Hutchinson: London, UK, 1965.

58. Giles, J. No Self to be Found: The Search for Personal Identity; University Press of America: Lanham, MD, USA, 1997.

59. Kjellgren, A.; Lyden, F.; Norlander, T. Sensory Isolation in Flotation Tanks: Altered States of Consciousness and Effects on Well-Being. Qual. Rep. 2008, 13, 636-656. [CrossRef]

60. Milliere, R. Are There Degrees of Self-Consciousness? J. Conscious. Stud. 2019, 26, 252-282.

61. Hale, J. Body Schema. In Understanding Merleau-Ponty, Understanding Modernism; Mildenberg, A., Ed.; Bloomsbury Academic: New York, NY, USA, 2019.

62. Zahavi, D. Husserl's Intersubjective Transformation of Transcendental Philosophy. J. Br. Soc. Phenomenol. 1996, $27,228-245$. [CrossRef]

63. Schnell, A. Intersubjectivity in Husserl's Work. Meta 2010, 2, 9-32.

64. Gallagher, S. How the Body Shapes the Mind; Oxford University Press: Oxford, UK, 2005.

65. Gallagher, S.; Zahavi, D. The Phenomenological Mind; Routledge: Abingdon, UK, 2020.

66. Varela, F.J.; Thompson, E.; Rosch, E. The Embodied Mind: Cognitive Science and Human Experience; MIT Press: Cambridge, UK, 2016.

67. Thompson, E. Mind in Life; Harvard University Press: Cambridge, UK, 2010.

68. Russell, B. The Analysis of Matter; Spokesman: Nottingham, UK, 2007.

69. Eddington, A.S. The Nature of the Physical World; Cambridge University Press: Cambridge, UK, 1928.

70. Clark, A.; Chalmers, D. The Extended Mind. Analysis 1998, 58, 7-19. [CrossRef]

71. Harding, D.E. An Unconventional Portrait of Yourself; The Shollond Trust Kindle edition: London, UK, 2016.

72. Huxley, A. The Perennial Philosophy; Chatto \& Windus: London, UK, 1946.

73. Sartre, J.-P. The Transcendence of the Ego: An Existentialist Theory of Consciousness; Noonday Press: New York, NY, USA, 1957.

74. Albahari, M. Perennial Idealism: A Mystical Solution to the Mind-Body Problem. Philos. Impr. 2019, 19, 1-37.

75. Gallagher, S. Direct Perception in the Intersubjective Context. Conscious. Cogn. 2008, 17, 535-543. [CrossRef] [PubMed]

76. Toadvine, T. The Cogito in Merleau-Ponty's Theory of Intersubjectivity. J. Br. Soc. Phenomenol. 2000, 31, 197-202. [CrossRef]

77. Ware, O. Ontology, Otherness, and Self-Alterity: Intersubjectivity in Sartre and Merleau-Ponty. Symp. Can. J. Cont. Philos. 2006, 10, 503-513. [CrossRef]

78. James, W. Text-Book of Psychology; Macmillan: London, UK, 1892.

79. Baillargeon, R.; DeVos, J. Object Permanence in Young Infants: Further Evidence. Child Dev. 1991, 62, 1227-1246. [CrossRef]

80. Jones, S.S. Imitation in Infancy: The Development of Mimicry. Psychol. Sci. 2007, 18, 593-599. [CrossRef]

81. Oostenbroek, J.; Suddendorf, T.; Nielsen, M.; Redshaw, J.; Kennedy-Costantini, S.; Davis, J.; Clark, S.; Slaughter, V. Comprehensive Longitudinal Study Challenges the Existence of Neonatal Imitation in Humans. Curr. Biol. 2016, 26, 1334-1338. [CrossRef] [PubMed]

82. Slaughter, V. Do Newborns Have the Ability to Imitate? Trends Cogn. Sci. 2021, 25, 377-387. [CrossRef] [PubMed]

83. Meltzoff, A.N.; Moore, M.K. Imitation of Facial and Manual Gestures by Human Neonates. Science 1977, 198, 75-78. [CrossRef] [PubMed]

84. Meltzoff, A.N.; Moore, M.K. Newborn Infants Imitate Adult Facial Gestures. Child Dev. 1983, 54, 702-709. [CrossRef] [PubMed]

85. Wider, K. The Self and Others: Imitation in Infants and Sartre's Analysis of the Look. Cont. Philos. Rev. 1999, 32, 195-210. [CrossRef]

86. Jones, S.S. The Development of Imitation in Infancy. Philos. Trans. R. Soc. B Biol. Sci. 2009, 364, 2325-2335. [CrossRef] [PubMed]

87. Wellman, H.M.; Cross, D.; Watson, J. Meta-Analysis of Theory-of-Mind Development: The Truth about False Belief. Child Dev. 2001, 72, 655-684. [CrossRef] [PubMed]

88. Frankl, V.E. The Feeling of Meaninglessness: A Challenge to Psychotherapy. Am. J. Psychoanal. 1972, 32, 85-89. [CrossRef] [PubMed]

89. Titova, L.; Sheldon, K.M. Happiness Comes From Trying to Make Others Feel Good, Rather Than Oneself. J. Posit. Psychol. 2021, 1-15. [CrossRef] 